\title{
Irish Gymnasts on Tour: The Women's League and Women's Exercise in 1940s Ireland
}

\author{
Conor Heffernan
}

Department of Kinesiology and Health Education, University of Texas at Austin Austin, United States

(C) Conor Heffernan. This work is licensed under the Creative Commons AttributionNonCommercial-NoDerivatives 4.0 International License. To view a copy of this license, visit http://creativecommons.org/licenses/by-nc-nd/4.0/.

\begin{abstract}
In 1949 the Irish branch of the Women's League of Health and Beauty travelled to Stockholm, Sweden to take part in the second annual Lingiad Festival. Created the previous decade to celebrate the gymnastic system of Per Henrik Ling established in the early nineteenth-century, the Festival was a multisporting cultural event open to groups from around the world. One such group was the Women's League of Health and Beauty. Founded in London in 1930 by the Irish-born Mary Bagot Stack, the League marked the decade's most expansive form of exercise for women. Owing to the League's Irish connection, the first League branch came to Belfast in 1930 and was followed by a Dublin branch some years later. Open to women across the life cycle, the League was targeted at both the working woman and the stay-at-home mother. Where previous studies have examined the creation of the League in Ireland, this piece focuses on the League's appearance at the 1949 Lingiad. Despite numerous appeals for government funding, the League was forced to raise its own funds for the trip, a point which rankled many journalists both before and after the tournament. There was an inherent tension in the League's involvement. On the one hand, it offered new opportunities for female exercise and provided a fillip for further engagement. That withstanding, the ongoing difficulties experienced by the League in actually making it to Lingiad highlighted the secondary, and often forgotten, nature of women's exercise in Ireland at this time. Using memoirs, film and newspaper articles, the piece positions the League's Lingiad trip as symbolic of both the advances and restrictions inherent in women's exercise in mid twentieth-century Ireland.
\end{abstract}

Keywords: League of Health; Women's League of Health and Beauty; Lingiad; Physical Culture; Women's Gymnastics.

\section{Introduction}

Twenty-four Irish girls left Dublin Airport yesterday for London en route to Stockholm where they will represent this country at Stockholm Stadium to-morrow in the march past of 19 nations...

Irish Press (Dublin), 26 July, 1949. ${ }^{1}$

This event was a point of considerable pride for the unnamed journalist. The League of Health, Ireland's most recognisable outlet for women's exercise, was the national representative at an

\footnotetext{
1 'Health League Girls Leave for Sweden', Irish Press, 26 July 1949, 6.
} 
international gymnastic festival open to nations from across Europe. Led by Kathleen O'Rourke, this twenty-four-strong group would don Irish uniforms, proudly wave the Irish flag and mix with those from other nations. At a time when female sport, and female physical activity more generally, still held a secondary position in Ireland, the League of Health's international tour marked a new turn in female physical culture. ${ }^{2}$ The League were not a sporting organisation, but rather one engaged in purposive exercise. ${ }^{3}$ Physical culture, or purposive exercise, refers to those activities in which the development of the body is the primary objective. Unlike sport where goal or point scoring is the dominant focus, physical culture concerns itself with improving one's health, strength, muscularity or appearance. Physical culture was, in many respects, a precursor for the modern interest in gym going, keepfit exercise and communal health classes. A study of physical culture thus provides an insight into the noncompetitive, but equally engaging forms of women's exercise in the twentieth century. Discussing both sides of female exercise, as the present issue does, highlights the totality of women's exercise in all its forms.

How and why did the League of Health embark on such a journey? Why were they chosen to represent the Republic of Ireland and how was this decision received in the Irish press? The League's destination was the second Lingiad, an international festival created in honour of Swedish physical educationalist, Per Henrik Ling. ${ }^{4}$ Where the majority of participating countries sent a male and female team, the Irish delegation distinguished itself by only sending a women's team. The first Lingiad had taken place just prior to the outbreak of the Second World War in 1939 and welcomed over seven thousand gymnasts from thirteen nation-states. ${ }^{5}$ The second iteration, now held in a drastically different post-war Europe, one year after the resumption of the Olympic Games, promised much for those involved. It represented not only diversion, but also cooperation with others from a continent still overcoming the devastating effects of the Second World War. Certainly, this was the intention behind the 1948 London Olympics. In his official report on the games, Lord Burghley, President of the Organising Committee, claimed that the Games 'contributed . . . not only in the saga of sport, but also in the achievement of youth to rise above the jealousies of the world'. ${ }^{6}$ Sport could bring nations together. That, at least, was the hope.

The appearance of the League of Health at the Lingiad was significant for a number of reasons. First, the League, which was in essence a private health group, was chosen by the organisers to represent Ireland. Second, a great deal of media interest was generated in Ireland and Sweden by their appearance, both in the lead up to, and during the event. Third, League teachers formed important international bonds at the Lingiad which were later used to support female exercise in Ireland. This is not to say, however, that the League's involvement with the Lingiad was without its problems. Despite numerous appeals for government funding, the League was forced to raise its own funds for the trip, a point which rankled journalists before and after the event. There was an inherent tension in the League's involvement. On the one hand, it offered new opportunities for female exercise and provided a fillip for further engagement among members. That withstanding, the ongoing difficulties experienced by the League in making it to Lingiad highlighted the secondary, and often forgotten, nature of

\footnotetext{
${ }^{2}$ Such a point reiterates the importance of special issues such as this.

${ }^{3}$ Purposive exercise was first coined by Jan Todd in Building the Body Beautiful: Purposive Exercise in the Lives of American Women 1800-1875 (Macon: Mercer University, 1998).

${ }^{4}$ Dorothy S. Ainsworth, 'The International Scene-Summer, 1949', Journal of the American Association for Health, Physical Education, and Recreation 20, no. 9 (1949): 573-629.

${ }^{5}$ Ibid.

${ }^{6}$ A good overview of the games is given by Martin Polley, The British Olympics: Britain's Olympic Heritage 1612-2012 (Swindon: English Heritage, 2012), 128-132.
} 
women's exercise in Ireland. Seen in this way, the article positions the League's Lingiad trip as symbolic of both the advances and restrictions inherent in women's exercise in mid twentieth-century Ireland.

To illustrate this point, this piece divides attention between the League's creation in Ireland, the period leading up to the Lingiad and finally, the event and its aftermath for Irish exercisers. The piece thus stresses the slow, and often cumbersome, progress of female physical culture in Ireland. The League's appearance at the Lingiad may have been a victory for a private exercise group now taken to be a national team, but the diversity of those involved-who differed in their age, employment and marital status - spoke to much broader trends in female physical culture. This was a trip that crossed age and class boundaries, a trip which gave female physical activity a much-needed spotlight and a trip which highlighted the need for more attention to female exercise.

\section{I: Women of Health or Women of Beauty? The Women's League in Ireland}

One of the most fascinating aspects of the League of Health's journey to the Lingiad in Sweden was how recent the League's own history was. The League of Health was, in actuality, the Republic of Ireland's branch of the Women's League of Health and Beauty. Founded by the Irish-born Mary Bagot Stack in London in 1930, the Women's League of Health and Beauty was one of the fastest growing, and most expansive, forms of female exercise during the 1930s and 1940s. ${ }^{7}$ Targeted initially at the young, upper working- and lower middle-class woman, the League evolved into a multigenerational group open to women of all social classes. ${ }^{8}$ It is significant that, unlike other outlets, the League's classes were open to girls, their mothers and, in more than one instance, their grandmothers. ${ }^{9}$ In the past, historians have highlighted the expressive, and at times liberating, spaces created by the League, especially in the British context. One of the first studies on the League, conducted by J.J. Matthews in 1990, stressed the sheer fun found in League classes. ${ }^{10}$ Such fun created, in Matthews's research, an insulated space for women to express themselves in a playful manner through songs, fun games and physical activity. The League routinely stressed the need for fun in exercise, in ways not possible in other parts of life. A cursory glance at the League's teaching materials from the 1930s and 1940s suggests why this was the case.

In League classes, which could take up to ninety minutes, exercisers completed their movements to music. Often done with a piano and pianist in the room, exercises were named the 'wiggle waggle', the 'seal' and a host of other playful terms. ${ }^{11}$ The classes themselves represented a unique platform for female bonding and friendship. Eilidh Macrae's pioneering work in this regard proves illustrative. One of the few studies to incorporate oral histories when dealing with League stories, Macrae's research continually returned to her contention that the League's popularity stemmed in large part from the uniqueness, diversity, and entertainment

\footnotetext{
${ }^{7}$ Patricia Vertinsky, "Building the Body Beautiful” in The Women's League of Health and Beauty: yoga and female agency in 1930s Britain', Rethinking History 16, no. 4 (2012): 517-542; Jill Julius Matthews, 'They had such a lot of fun: The Women's League of Health and Beauty between the wars', History Workshop Journal 30 , no. 1 (1990): 22-54.

${ }^{8}$ Here class is understood with reference to one's access to the wealth of their society. A short, but worthwhile, discussion of social and economic class in Ireland is in Maura Cronin, 'Class and status in twentieth-century Ireland: the evidence of oral history', Saothar 32 (2007): 33-43.

${ }^{9}$ The Editor, 'Personalities: Mrs. King', Mother and Daughter 7 (1934): 32.

${ }^{10}$ Matthews, 'They had such a lot of fun'.

${ }^{11}$ Prunella Stack, The Way to Health and Beauty (London: Self-Published, 1938), 6-10.
} 
derived from League classes. ${ }^{12}$ Such diversity was not an accident or stroke of luck, but marked a deliberate attempt by the League's founder, Mary Bagot Stack, to create a targeted form of female exercise.

Bagot Stack went on record at several points during the 1930s to decry the state of female physical culture more generally. In 1931, Bagot Stack claimed that previous systems of exercise for women were unsatisfactory because women's exercise systems were often ersatz versions of the systems created by men for men. Equally troublesome was the fact that such systems were based on male ideas of the ideal female form. This, as Bagot Stack sardonically noted, was problematic because men were blown 'hither and thither' with regards to the female form. ${ }^{13}$ This point highlighted Bagot Stack's own awareness of the constructed nature of the ideal body and the influence of male voices in women's exercise. Contrasting this state of affairs was the League, whose exercise system was designed by women, implemented by women and undertaken in an all-female setting. That this kind of female exercise class was almost entirely unique in the British and Irish contexts explains, in part, why early histories of the League depicted the organisation as revolutionary. ${ }^{14}$ It may also explain how and why the League enjoyed such attention and prestige during the 1930s. When the British government created a public body tasked with improving health and well-being among the populace in the late 1930s, League members were chosen to act on the Committee's board. ${ }^{15}$ That the League was not yet a decade old spoke of its importance and public profile.

Aside from Mary Bagot Stack's own Irish heritage, a heritage she continually wrote about during the 1930s, there were strong links founded with Ireland. In the autumn of 1930, the League's first overseas branch was established in Belfast, albeit not without some considerable trouble. ${ }^{16}$ Four years after the Belfast branch's foundation, League member Peggy Matthews recalled the difficulties encountered trying to establish classes. Aside from struggling to find the correct venue, League members found it difficult to attract interest in the classes. Their trouble stemmed, in part, from the Belfast League's relative obscurity, at least compared to its later fame. ${ }^{17}$ When these issues were overcome through word-of-mouth recommendations and fundraising events, the League flourished. Within two years, the Belfast branch catered to over two hundred women before interest grew further. At the mid-decade point, the Belfast League had over one thousand fee paying members, all of whom contributed two shillings and six pence for their yearly membership. ${ }^{18}$ It also had its own headquarters where women could meet, socialise and host fundraising balls. That the Belfast branch owned its own headquarters and meeting place from 1935 meant that women were no longer forced to travel to different training centres to exercise together. They now had a centralised meeting place akin to a sports ground or stadium. ${ }^{19}$

Despite the League's popularity in Belfast, it took another four years before another Irish branch was opened, this time in Dublin. Interestingly, the League largely constituted itself

\footnotetext{
${ }^{12}$ Eilidh Macrae, Exercise in the Female Life-cycle in Britain, 1930-1970 (Basingstoke: Palgrave Macmillan, 2016), 33-88. See also Mary Bagot Stack, Building the Body Beautiful (London: Chapman and Hall, 1931; seventh impression 1938), 12.

${ }^{13}$ Bagot Stack, Building the Body Beautiful, 12.

${ }^{14}$ Matthews, 'They had such a lot of fun'. See also Lynn Ashburner, In a League of Their Own: The Story of the Women's League of Health and Beauty (London: Heritage Books, 2005).

${ }^{15}$ Ina Zweiniger-Bargielowska, 'The Making of a Modern Female Body: beauty, health and fitness in interwar Britain', Women's History Review 20, no. 2 (2011): 299-317.

${ }^{16}$ Mary Bagot Stack, The Romance of the League (London: The Women's League of Health and Beauty, 1934), 12.

17 'News from the Branches', Health and Beauty Magazine 1 (1933): 41.

18 'How we Grow', Mothers and Daughters 14 (1935): 11.

${ }^{19}$ Ibid.
} 
as an all-Ireland organisation. While differences did exist between members in the Free State and Northern Ireland, not least regarding clothing, the Irish branches were treated by the League as a single entity. This was evidenced in the League's internal writings and also promotional material. ${ }^{20}$ As evidenced by the increasing membership numbers in Northern Ireland, this was not due to a lack of interest, but rather expertise. When the Belfast branch was opened, the founding member Eileen MacMurray had been specifically trained by Mary Bagot Stack to bring her system to Ireland. ${ }^{21}$ For future branches to open, it required an enthusiastic Irishwoman to travel to England, train under Mary Bagot Stack and return to Ireland. ${ }^{22}$ That it took four years to find a willing volunteer highlights some of the structural barriers to female exercise that existed in the interwar period. In male physical culture and sport, a lack of coaching expertise was rarely, if ever, a problem. Male physical culture or gymnastic instructors could typically be chosen from the military, the police force, individual gymnasia or individual schools. ${ }^{23}$ Such a diverse pool was simply not available for female instructors. Individual physical education colleges for women existed, like Alexandra or Ling College, but the numbers available were low. This explains why, prior to the League's emergence, in many instances female physical activity classes in the Republic of Ireland were typically led by men. ${ }^{24}$ For the League, a person was eventually found in the form of Kathleen O'Rourke, a young Irish student who had recently graduated from the Liverpool College of Physical Education. ${ }^{25}$ O'Rourke, who later led the League team at the Lingiad, became a driving force in female exercise in the Free State and subsequently the Republic of Ireland following the renaming of the State in 1948. She helped create branches around Ireland, trained members, mentored coaches and hosted fundraisers.

With the Belfast branch as the template, the Dublin branch enjoyed a great deal of success. Unlike the Belfast branch's somewhat disorganised and underwhelming opening, O'Rourke's first Dublin class in 1934-designed to be an introductory class-welcomed nearly six hundred spectators. Of these, over four hundred signed up as members. An oftrepeated anecdote among League members and the League's official magazine at this time centred on an unnamed Dublin man who complained to his wife that 'you girls and your Health and Beauty, you talk of nothing but your League!'26 The anecdote came to represent the excitement and attention given over to the League by its new members. It took four years to establish a second branch in Ireland, but from there, the League's momentum grew. By the end of the 1930s several other branches were established north and south, including those in Cork, Larne, Dundalk and Ballymena. ${ }^{27}$ Remarkably — given the relative distances, partition and the tensions that arose from this - branches were in almost continual contact with one another, as evidenced by the many collaborative classes and fundraising events held across branches. The interactions between League branches throughout Ireland was unsurpassed compared with other realms of female physical activity, aside from hockey and golf, the latter of which was one of the earliest modern 32-county sports to be established for women. ${ }^{28}$ When a Ballymena branch opened in 1937, its introductory class featured a demonstration from Belfast. That same

\footnotetext{
${ }^{20}$ Conor Heffernan, 'Fitness and fun that's not just for mum: the Women's League of Health and Beauty in 1930s Ireland', Women's History Review 28, no. 7 (2019): 1017-1038.

21 'News from the Branches', Health and Beauty Magazine 1 (1933): 41.

${ }^{22}$ Stack, The Romance of the League, 17-20.

${ }^{23}$ Conor Heffernan, 'Physical culture and Irish modernity, 1893 to 1918', Leisure/Loisir 43, no. 2 (2019): 159184.

${ }^{24}$ Stack, Building the Body Beautiful, 12.

25 The League of Ireland, Diamond Jubilee 1934-1994 Booklet (Dublin: Self-Published, 1994), 8-10.

26 'News from the Centres', Mothers and Daughters 10 (1934): 13.

27 'Larne', Health and Beauty 39 (1939), 30.

28 John Lucey, 'Women's Hockey in Ireland - A Short History', History Ireland 26, no. 5 (2018): 44-47; Ivan Morris, A History of Women's Golf in Ireland (Dublin: Liberties Press, 2018).
} 
year O'Rourke and her Dublin class travelled to Belfast to celebrate the latter's seventh anniversary. They were joined by classes from Portadown and Ballymena. ${ }^{29}$ In 1939, the Larne branch welcomed public exhibitions of League exercises from the Belfast, Ballymena and Dublin branches for its grand opening. ${ }^{30}$

Thus far, a largely celebratory and unproblematic account of the League in Ireland has been given. While it is true that the League enjoyed a great deal of success in establishing itself in the island of Ireland, structural barriers and prejudices still existed. Aside from her first-class diploma from Liverpool, Kathleen O'Rourke was also distinguished by her familial background; she was a cousin of then Bishop John Charles McQuaid. ${ }^{31}$ McQuaid, who became Archbishop of Dublin in 1940, was known for his restrictive understandings of femininity and, indeed, of female sport. ${ }^{32}$ McQuaid's political power at this time is clear as evidenced by his advisory role on political issues, such as the new Irish Constitution of $1937 .{ }^{33}$ While McQuaid's influence over the course of female sport in Ireland has yet to be fully explored, aside from his disapproval of mixed athletics in 1940, his influence over the Women's League in Ireland was clear. $^{34}$

On hearing of the establishment of the League in Dublin, McQuaid met with O'Rourke to outline changes that would need to be made before the group could come to the Republic of Ireland. Possessing no official power to prevent the group coming to Dublin, McQuaid's societal influence and public persona were enough to force some modifications be made. In the first instance the group's name was changed from the Women's League of Health and Beauty to The League of Health. ${ }^{35}$ It was a somewhat subdued change that, in reality, became quite significant. The Women's League of Health and Beauty moniker had begun to spread around the globe and would, by the end of the decade, be found in Great Britain and Northern Ireland, the Irish Free State, India, New Zealand, Australia and Canada. ${ }^{36}$ In no other territory did a branch have to change or modify its name. That the Free State branch was encouraged, if not partially constrained, to do so marked it out as a unique group, one distinguishable from the rest of its growing international community. This point was obvious to members who, in the League's magazine during the 1930s, often distinguished between the Women's League in the Free State and that in Northern Ireland by regarding the group's sartorial decisions and promotions. Such differences were not, however, enough for the League not to be regarded as an all-island entity in Ireland. ${ }^{37}$

The other, and more significant changes, suggested by McQuaid related to the League's public image. At its founding in 1930, the Women's League chose for its symbol a silhouette of League teacher Peggy St. Lo leaping gracefully through the air (Fig. 1). ${ }^{38}$

\footnotetext{
29 'News from Northern Ireland', Health and Beauty 30 (1937): 34.

30 'Larne', Health and Beauty.

31 The League of Ireland, Diamond Jubilee, 8.

32 Deirdre Raftery and Catriona Delaney, "Un-Irish and un-Catholic": sports, physical education and girls" schooling', Irish Studies Review 27, no. 3 (2019): 325-343.

${ }^{33}$ Sean Faughnan, 'The Jesuits and the Drafting of the Irish Constitution of 1937', Irish Historical Studies 26, no. 101 (1988): 79-102.

${ }^{34}$ John Cooney, John Charles McQuaid: Ruler of Catholic Ireland (New York: Syracuse University Press, 2000), 80 .

${ }^{35}$ Heffernan, 'Fitness and fun', 1017-1038.

${ }^{36}$ Matthews, 'They had such a lot of fun'.

${ }^{37}$ Heffernan, 'Fitness and fun', 1022-1025.

${ }^{38}$ Ibid.
} 


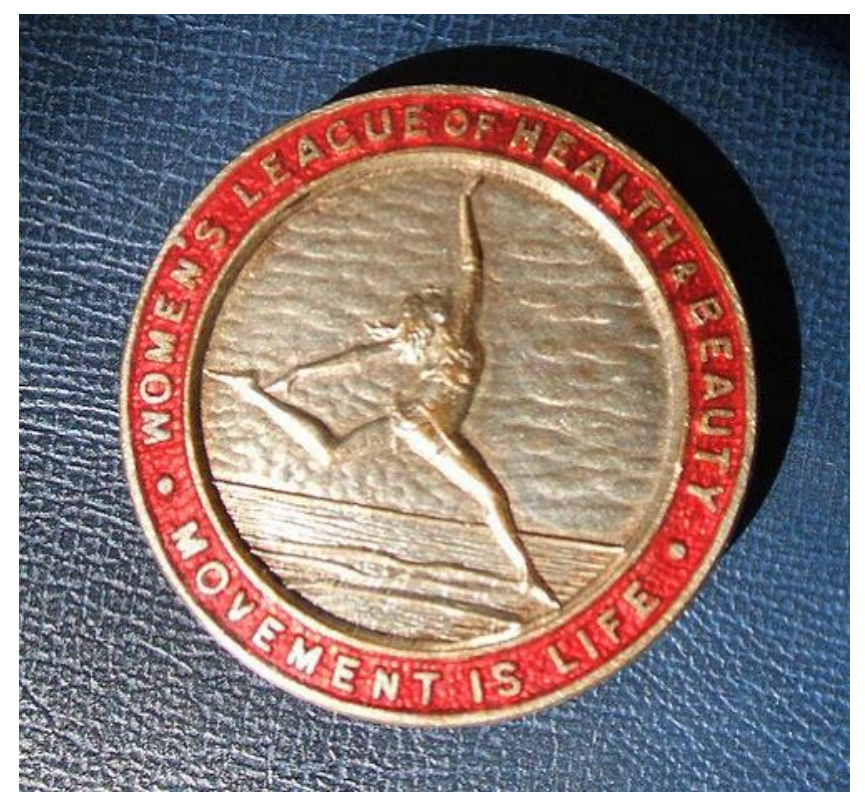

Fig. 1. The Traditional Women's League Badge, c. 1930s. ${ }^{39}$

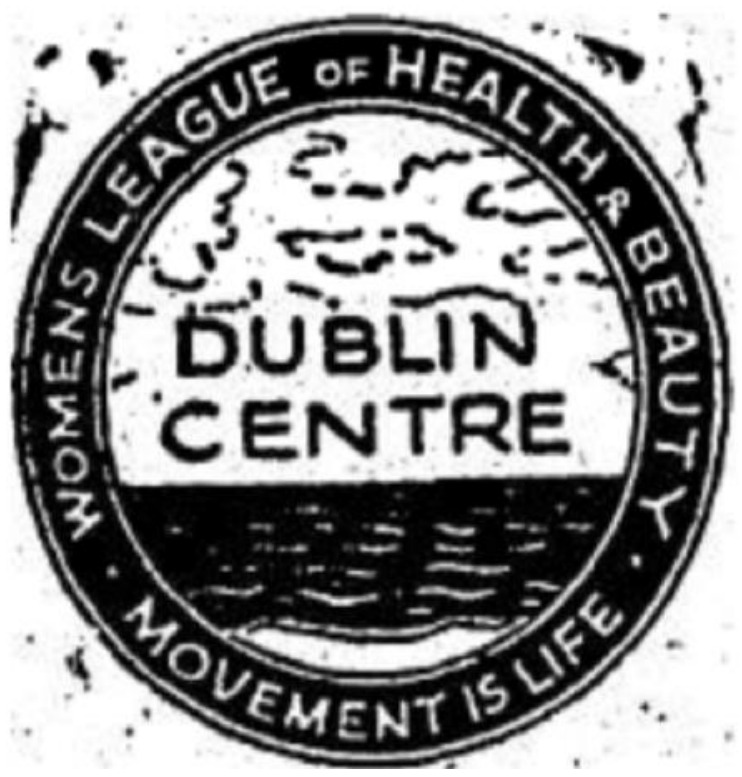

Fig. 2. The modified Free State badge. ${ }^{40}$

Deemed provocative by McQuaid, the Dublin branch changed its logo to a simple text box with Dublin written across it (Fig. 2). ${ }^{41}$ Such changes suggested that despite the League's adherence to gendered norms, even symbolic allusions to female physicality were too provocative for McQuaid. Stylistic changes such as these were also found in the attire of Free State branches. The traditional League uniform was a white tunic with black shorts. On McQuaid's recommendation, the then- Free State branch added a skirt to the uniform, which would have brought the League's uniform in line with other women's sports like hockey or golf. This decision, as League teacher Isolde McCullough later wrote, proved rather impractical. A great

\footnotetext{
${ }^{39}$ From author's collection.

${ }^{40}$ Irish Press, 30 August 1940, 6.

${ }^{41}$ Ashburner, In a League of Their Own, 44-45.
} 
deal of League classes were conducted on the floor, doing exercises with one's feet in the air. ${ }^{42}$ This meant that during classes, members had to continually battle with their skirts turning upside down. This may have mattered little in a private exercise class with one's friends, but was problematic in public demonstrations. Letters from this time include League founder Mary Bagot Stack's order to Kathleen O'Rourke to do whatever was necessary to open a Dublin branch. In this, O'Rourke complied with her instructions, giving way to some of McQuaid's recommendations with little indication as to whether or not such changes would be permanent. ${ }^{43}$ They were to last for several years. In fact, equanimity between the Northern and Free State branches in terms of clothing came in the 1940s. Both groups retained different names until the League was rebranded the Fitness League later in the twentieth century.

Despite the somewhat troubled opening of the Dublin branch, the League's popularity grew on the island of Ireland, on both sides of the political border during the course of the 1930s. Its growth was tracked by the steady increase of women in the workforce who largely aligned with the League's key demographics of eighteen to thirty years of age. ${ }^{44}$ At the outbreak of the Second World War in 1939 League members were in the thousands, with the majority of members found in Belfast and Dublin. ${ }^{45}$ In line with the London branch, Irish classes were temporarily suspended for the first year of the War, before returning, tentatively, in $1940 .{ }^{46}$ That the League was able to continue classes during the War and thus keep a space open for women to exercise, explains the League's strong position in Ireland in the post-War period. Some of this strength lay in the political position of Éire/Ireland, which remained neutral during the War, thereby avoiding excessive disruptions and destruction. ${ }^{47}$ Equally important, however, was the enthusiasm maintained by the League in holding classes, balls and demonstrations.

\section{II: Getting to the Lingiad}

That the League held an importance for women's exercise in Ireland is clear. It was one of the few groups to target women across the life cycle, maintained its own corps of dedicated teachers and managed to not only exist, but thrive during and after the Second World War. Certainly, the mid- to late-1940s saw the League, and its teachers, gain a much more prominent position in the Irish media. Illustrative of this was Kathleen O'Rourke, the leader of the Dublin branch who, from 1946, published a weekly health column in the Irish Press. ${ }^{48}$ This was not the first time that a woman had been given a column on personal exercise in the Irish media, because such columns had existed sporadically from the late nineteenth-century. ${ }^{49}$ It was, however, the first time that a woman with a direct link to a fitness or sporting organisation was given a regular platform. Detailing everything from fat loss to correcting rounded shoulders, O'Rourke's Irish Press columns helped further both her, and the League's social capital, in Ireland. ${ }^{50}$ Isolde McCullagh's later reminiscences spoke of the importance that publicity such as this gave to the organisation. ${ }^{51}$ Unaffiliated with any of the Irish sporting federations and

\footnotetext{
${ }^{42}$ Isolde McCullagh, Isolde's Way (Wicklow: Self-Published, 2004), 50.

${ }^{43}$ Ashburner, In a League of Their Own, 44-45.

${ }^{44}$ Mary E. Daly, 'Women in the Irish Free State, 1922-39: the interaction between economics and ideology',

Journal of Women's History 7, no. 1 (1995): 99-116.

45 'The Women's League of Health and Beauty', Health and Beauty 39 (1939), 2.

46 'League of Health', Belfast Newsletter, 21 February 1940, 7.

${ }^{47}$ Ronan Fanning, 'Irish neutrality: An historical review', Irish Studies in International Affairs 1, no. 3 (1982): 27-38.

${ }^{48}$ Kathleen O’Rourke, 'Taking Off Surplus Fat', Irish Press, 5 December 1946, 3.

49 'Women's Progressive Union', Dublin Daily Express, 15 February 1899, 2.

${ }^{50}$ Kathleen O’Rourke, 'Learning to Relax', Irish Press, 2 November 1946, 3.

${ }^{51}$ McCullagh, Isolde's Way, 91-95.
} 
operating on the border between capitalism and charity, the League was treated by the general public with a level of respect in the realm of female fitness. Despite the name change, the League was still part of the Women's League of Health and Beauty which meant that it also held an international importance.

This explains, in part, why the League was invited to take part in the 1949 Lingiad alongside teams from Northern Ireland and Great Britain. A recent article by Conor Curran details the career of Joan Burnett Knight, a physical educationist in Northern Ireland who led a Northern Irish delegation to the Lingiad. ${ }^{52}$ Knight, who helped the facilitate the spread of female physical education programmes across Northern Ireland, was entrusted with heading two all-female teams at the Lingiad. While the first team was comprised of gymnasts, the other was tasked with providing an Irish dancing demonstration at the Games. Knight was not a member of the Women's League of Health and Beauty in Northern Ireland but rather a physical educationalist. That she was chosen to lead a team suggests that the strength of physical education for women in Northern Ireland outmatched that of the Republic of Ireland, given that no female physical educationalist unaffiliated with the League was asked to participate in the Republic. ${ }^{53}$ Returning to Kathleen O'Rourke, it is not obvious how she was co-opted to be part of the Festival, but it is clear that the invitation was talked about in public for several weeks prior to the event. ${ }^{54}$

The Lingiad itself was a celebration of the teachings and impact of Per Henrik Ling. Ling, whose teachings spread throughout Europe and North America, was a nineteenth-century physical educationalist whose method of 'Ling' or 'Swedish Gymnastics' came to be one of the century's most popular forms of recreational and remedial gymnastics alongside Turnen and other forms of military drill. ${ }^{55}$ To celebrate Ling's legacy, the Swedish government organised a mass gymnastics tournament in 1939, the centenary of Ling's 1839 death. On 20 July 1939, the first Lingiad was held at Stockholm Stadium. The event was organised by the Swedish Gymnastics Association and, rather remarkably, welcomed 7,399 gymnasts from thirty-seven countries. The largest delegation came from Denmark with 1,900 participants, where Germany sent one thousand participants. ${ }^{56}$ The second Lingiad took place as planned in 1949. Building on the previous celebration, the 1949 games welcomed roughly fourteen thousand participants from nineteen countries. Although it ultimately resulted in a financial loss for the Swedish Gymnastics Association, it was a success. No further Lingiads were held, but the spirit of the events continued with the foundation of the World Gymnaestrada, which, in effect, is a World Cup of gymnastics held every four years. ${ }^{57}$

Turning to Irish participation at the games, it is notable that while most countries sent a male and female gymnastics team, Ireland sent a women's team only. Despite the fact that male gymnastics were equally popular in Ireland, it is likely that the League's global contacts facilitated their official invitation from the organisers. ${ }^{58}$ A point of major contention in the Irish

\footnotetext{
${ }^{52}$ Conor Curran, 'The development of physical education in Northern Ireland, 1922-1953 and the role of Joan Burnett Knight', Sport in Society (2020): 1-21.

53 Ibid.

54 'Day to Day', Irish Press, 26 July 1949, 4.

${ }^{55}$ Philip A. Smithells, 'Going to the Lingiad?', Journal of the American Association for Health, Physical Education, and Recreation 20, no. 2 (1949): 94; Joseph Maguire, 'European body cultures and the making of the modern world: Zones of prestige and established-outsider relations', Human Figurations 1, no. 1 (2012). ${ }^{56}$ Smithells, 'Going to the Lingiad?', 94.

${ }^{57}$ Angela Wichmann, 'Diversity versus unity: a comparative analysis of the complex roots of the World Gymnaestrada', The International Journal of the History of Sport 32, no. 4 (2015): 614-629.

${ }^{58}$ Although the Irish Amateur Gymnastics Association was not founded until 1964, Sheila Champion's work discusses the popularity of male gymnastics in Ireland during this time; Sheila Champion, Irish Amateur
} 
press at the time of the invitation was the fact that the Irish government was not going to provide funding for the League's trip, despite requests to do so. This action mirrored the government's action one year prior, declining to fund the Irish Olympic teams departing for the London games. Janie Hampton's work on the Games notes that the Irish team borrowed money to attend the Olympics and sustained themselves largely on sandwiches. ${ }^{59}$ The government's decision to withhold funding for the League meant that the League was forced to raise its own money for uniforms, travel and accommodation. The indignation this caused was evident in an article published for the Irish Press in June 1949 in which the journalist, Anna Kelly, stated that:

It is curious enough that although this branch of women's education has been so neglected here (until the League tackled it) it should be a women's team who are invited on the first occasion that Ireland has a chance of being represented abroad ...

A delegate at the Fianna Fáil Ard-Fheis remarked last week that "as a propaganda asset Mrs. Fanny Blaners-Koen was worth hundreds of thousands of pounds to Holland. They had men in Ireland to represent them internationally if given the opportunity [this was a reference to the 1948 Olympic Games] ... "

Change "men" to "women" and here's the opportunity, a team of Irish girls all dressed up in twinkling green and white uniforms, ready and waiting to go. ${ }^{60}$

Despite such pleas, the League generated one thousand pounds through their own fundraising efforts. This was eventually achieved through the use of members' subscription fees, public appeals and a number of fundraising events. ${ }^{61}$ This was not the first time that the League had been forced to rely on its own fundraising events. During the 1930s, the League routinely held dances, tea mornings and public demonstrations as a means of purchasing properties and equipment. ${ }^{62}$ Government funding was promised in some instances - as was the case in Northern Ireland in the late $1930 \mathrm{~s}$ - but was rarely given. ${ }^{63}$ This did not cause much outcry during the 1930s, but it did in the following decade as state policy towards sport began to change around the world, evidenced by the ways in which training, equipment and state-funded coaching methods became items for discussion at meetings of national and international Olympic and athletics committees. By the 1940s, the use of sport for the purposes of soft power was becoming much clearer, especially on the international stage. ${ }^{64}$

Writing in the Irish Press in 1949, Kelly made clear the difficulty placed on the League by fundraising in the months preceding the trip. Undertaken at a time when it was unclear whether or not the League would succeed in raising enough money, Kelly practiced little diplomacy in making clear their situation:

They will have to hold their own with physical culture teams from 46 other nations ... This end of the job is not bothering them overmuch. The worry is what they are going to use for money . ... There is little or no cash in the concern, for the League is practically a non-profit-making

Gymnastics Association: History of the First 25 Years (Dublin: IAGA, 1989), 1-5. See also Heffernan, 'Physical culture and Irish modernity'.

59 Janie Hampton, The Austerity Olympics: When the Games Came to London in 1948 (London: Aurum Press Limited, 2012), 44-45.

${ }^{60}$ Anna Kelly, 'League of Health', Irish Press, 23 June 1949, 3.

${ }^{61}$ McCullagh, Isolde's Way, 91-95.

${ }^{62}$ Heffernan, 'Fitness and fun', 1025-1030.

${ }^{63}$ Ibid., 1029-1034.

${ }^{64}$ Barbara Keys, 'The early Cold War Olympics, 1952-1960: Political, economic and human rights dimensions', in The Palgrave Handbook of Olympic Studies, ed. Helen Jefferson Lenskyj and Stephen Wagg (London: Palgrave Macmillan, 2012), 72-87. 
organisation. And they want $£ 1,000$ for travelling expenses and if they don't get it they can't go $\ldots 65$

Continuing in this vein, Kelly noted that while other teams were being financed by their governments, the Irish team was not. This not only deprived the League of appearing at the Lingiad, but meant that Ireland would be the 'only country not represented' at Stockholm should they fail to fund themselves. ${ }^{66}$ That the Irish Press, the same periodical which featured Kathleen O'Rourke, would support the League was unsurprising. It was not, however, alone in its support. Prior to the event the Evening Herald (Dublin) featured pieces from the Swedish Minister to Ireland, Oscar Thorsing, expressing his hope that the Irish government or the 'public spirited people of Ireland' would fund the journey. ${ }^{67}$ The then Minister for Education, General Richard Mulcahy, was also interviewed about the League's participation but the most he would publicly offer was his ideological support. ${ }^{68}$ The same approach was found in the Irish Olympic Council's attempts to bolster government support for their contestation of the political boundary rule in sport which influenced athlete selection in Olympic Games. ${ }^{69}$

Despite murmurings of discontent, the League was left to fundraise the trip through subscriptions. In this, much was made of the fact that the women themselves came from a variety of professions and backgrounds. Counted among them were shop assistants, typists, dressmakers, housewives, students and mothers as well. ${ }^{70}$ The youngest of the group was Dallas McCullagh at eight weeks (Fig. 3), who travelled with his mother, the League teacher Isolde McCullagh, to the event. ${ }^{71}$

\footnotetext{
${ }^{65}$ Kelly, 'League of Health'.

${ }^{66}$ Ibid.

67 'League of Health Team for Sweden', Evening Herald, 5 July 1949, 3.

${ }^{68}$ Ibid.

${ }^{69}$ Katie Liston and Joseph Maguire, 'Making sense of 'Ireland', sport and identity: the craft of doing sociology', Sport in Society (2020): 1-19.

70 'Day to Day', Irish Press, 26 July 1949, 4.

${ }^{71}$ Kelly, 'League of Health'.
} 


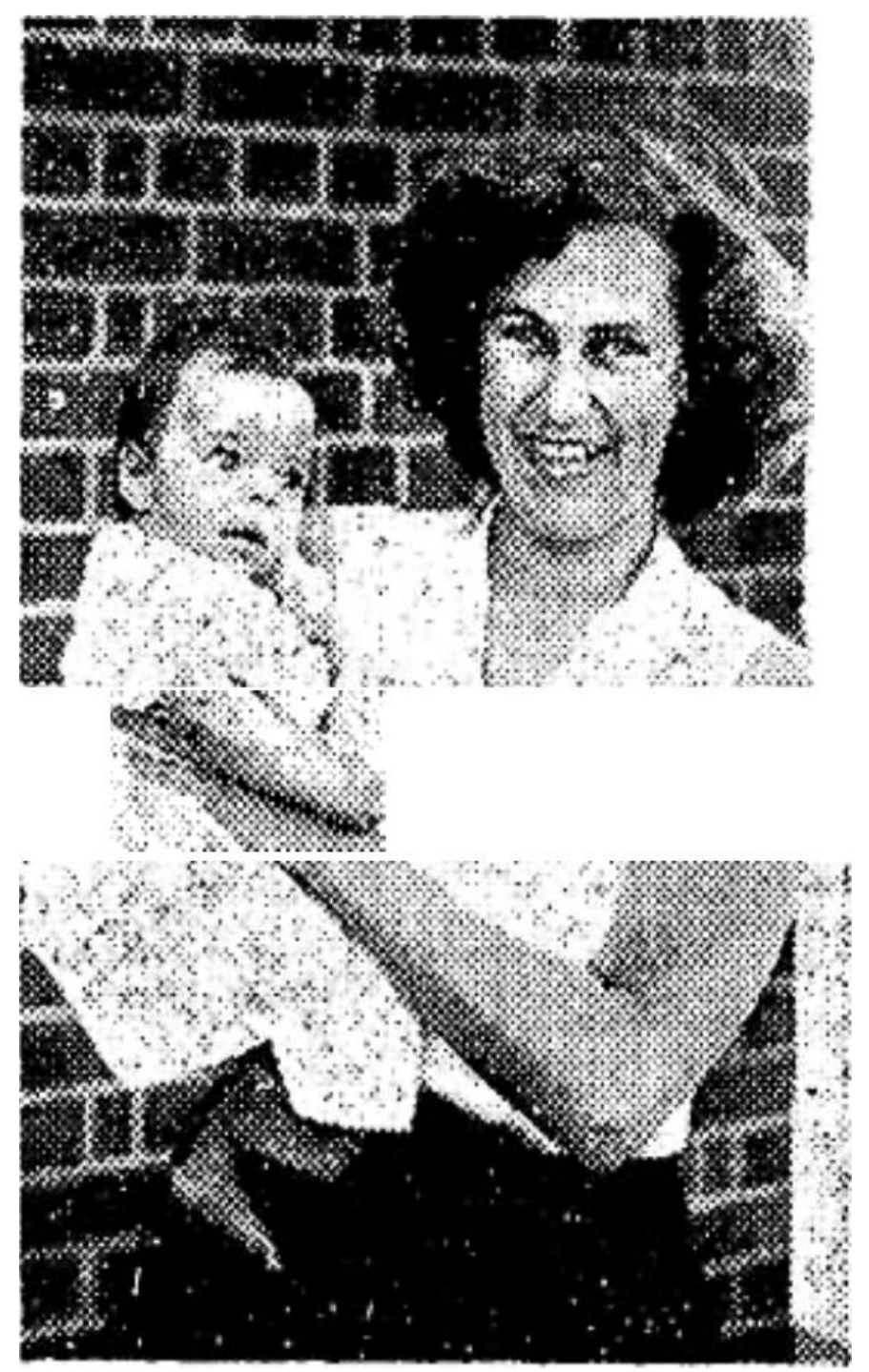

Fig. 3. Dallas and Isolde McCullagh. ${ }^{72}$

It is worth pausing, momentarily, to discuss Isolde and Dallas McCullagh's involvement in the Lingiad. In the lead up to the League's trip to Sweden, newspapers in Ireland and Northern Ireland began to focus on the story of Isolde's small son, Dallas. Isolde's decision to travel with her child was presented as almost entirely unusual in the Irish press. ${ }^{73}$ In comparing and contrasting the Northern Irish team and the Irish teams, the Belfast Telegraph opened with the headline 'Baby must go too' when discussing the difficulties facing the League of Health. ${ }^{74}$ That the child went with Isolde to Sweden rather than staying with her husband in Dublin, whose name and profession was printed in these reports, became one of a major talking point of the journey once it became clear the League had secured the money to finance the trip. Such attention, lighthearted though it was at times, spoke to a very real, and often neglected aspect of women's sport in Ireland-namely, motherhood. It also spoke of a social current, in the Republic, that decried sportswomen's supposed neglect of their children, for example, the response to Maeve Kyle's participation in the 1956 Melbourne Olympics. Katie Liston's paper in this issue gives a fuller explanation on the theme of shame in Maeve Kyle's career.

\footnotetext{
${ }^{72}$ Kelly, 'League of Health', 3.

${ }^{73}$ Ibid.

74 'Baby Must Go Too', Belfast Telegraph, 28 July 1949, 3.
} 
In the Scottish context, Eilidh McCrae's life history of Scottish athletes stresses the recurring and always present influence that marriage and womanhood had over women's athletic careers in the mid to late twentieth-century. ${ }^{75}$ For some, playing sport or remaining part of an organisation became almost impossible once they got married and/or had children. Part of this stemmed from medical advice given at the time, especially with regards to the safety of pregnant women exercising. Oftentimes, however, it resulted from the expectation that once married, women no longer had time for, or should devote time to, their own pursuits. ${ }^{76}$ This, of course, was not unique to Scotland. In a different vein, Samantha Oldfield's detailed study of British netball finds that many of the sport's founding members in the late nineteenthcentury were those who remained unmarried and hence free to volunteer their time and efforts. ${ }^{77}$ It is an important point to state that among the twenty-four women who travelled to Sweden on the Irish contingent, several were mothers.

In recreational circles, the League's association with motherhood had been well founded. Aside from the fact that for many years their magazine was called Mother and Daughter, advertisements for League classes promoted the idea that the League was open to everyone from the young child to the active grandmother. ${ }^{78}$ Within the League the practice of bringing children to class was not only commonplace but encouraged. Many lifelong members were first exposed to the League when brought to classes as children. ${ }^{79}$ When Isolde decided to bring Dallas to Sweden it was not an overtly political statement, nor was it unusual within the norms of the League. The League thus fulfilled an important outlet for women. Its importance was made clear in the Irish Independent (Dublin) prior to the trip in which an unnamed reporter claimed that 'competitive athletics for women shows little signs of becoming popular in this country'. ${ }^{80}$ The League was concerned more so with physical education than sport, but it nevertheless made possible a discussion about athleticism and motherhood in a public sphere which, in the main, did not encourage the former at the supposed or perceived expense of the latter. Even prior to the 1937 Free State Constitution, which referred to woman's position in the home, female involvement in the public sphere was discouraged by political, religious and social groups in Ireland. ${ }^{81}$ The build-up to the League's trip to Sweden, which was undertaken in late July of that year, showcased both the material strictures of women's exercise and the practical struggles of women attempting to balance their interest in activity with domestic duties.

\section{III: The Lingiad and its Legacy}

Once it became clear that the League of Health would make it to Sweden for the Lingiad, newspaper articles and public interviews shifted from reflective commentary on women's sport in Ireland to excitement about the League's participation. This, as certain journalists made clear, was the first time that a team of Irish women had been invited to present at a global festival. ${ }^{82}$ To put this into context, while Irish women had competed against one another in camogie, and against international teams in once-off soccer (association football) matches, the

\footnotetext{
${ }^{75}$ Eilidh Macrae, Exercise in the Female Life-cycle in Britain, 1930-1970 (Basingstoke: Palgrave Macmillan, 2016), 45-88.

76 Ibid.

${ }^{77}$ Samantha Oldfield, 'The origins and formation of England Netball' (International Sport and Leisure History Colloquium, Manchester Metropolitan University, 3-4 March 2017, Crewe, UK).

${ }^{78}$ Heffernan, 'Fitness and fun', 1020-1030.

79 Ibid.

80 'The League of Health', Irish Independent, 26 July 1949, 3.

${ }^{81}$ Caitriona Beaumont, 'Women, citizenship and Catholicism in the Irish free state, 1922-1948', Women's History Review 6, no. 4 (1997): 563-585.

${ }^{82}$ Ibid.
} 
concept of an Irishwoman or Irishwomen competing in an international tournament was patchy at best. ${ }^{83}$ While four Irishwomen competed in the 1948 Olympics in art, in sport only Dorothy Dermody represented Ireland in fencing. Such women followed in the footsteps of Beatrice Hill-Lowe, a medallist in archery in 1908 for Great Britain, and Sophie Mary Peirce-Evans, who helped found the English Women's Amateur Athletic Association in the early 1920s. From the League's Lingiad showing, it took another seven years for an Irishwoman to compete in an international tournament, when Maeve Kyle competed in the 1956 Melbourne Olympics. ${ }^{84}$ That Kyle faced similar funding issues to the League was telling of the position of women's physical activity, and state funding for sport, in Ireland.

The League had previously travelled to London on a near annual basis to participate in yearly demonstrations but this was the first time it travelled to mainland Europe. ${ }^{85}$ It was the first time that the League joined a global community of men and women dedicated to the practice of gymnastics. From 27 July to 13 August thousands of male and female gymnasts descended on Stockholm to take part in the Lingiad. What cannot be understated here is just how exciting the event was for those involved. Writing in the Journal of the American Association for Health, Physical Education, and Recreation, physical educationalist Dorothy Ainsworth of Smith College recorded the event as a great meeting of minds. ${ }^{86}$ Women from around the world were invited to demonstrate the relative benefits of their systems and learn from others. What particularly thrilled Ainsworth about this was that the Lingiad was a place to 'renew acquaintanceship, to talk over a problem, to meet experienced leaders in the field, to learn of and study new materials, to compare notes on program procedures ${ }^{87}$ Ainsworth's enthusiasm was corroborated by fellow American physical educationalist Gladys Andrews, who was invited to speak on the subject of children's health. It was through the encouragement of movement and activity that nations could, in Andrews's somewhat idealised philosophy, overcome political barriers and strife. Such comments echoed those found in Lord Burghley's rose-tinted evaluation of the 1948 Olympic Games. In this way, nations could produce the 'universal child of the future' ${ }^{88}$ It was not just American visitors who were impressed. Writing in the weeks preceding the event, New Zealand physical educationalist Philip A. Smithells described it as one of the most important events in the development of gymnastics as a whole. Having attended the first Lingiad in 1939, Smithells expressed his belief that such events should be held every decade..$^{89}$

The event itself was an intricate affair. The first five days were given over to 'practical instruction', by which it was meant pre-planned gymnastic displays. Following that, six days were allocated for lectures on health or the latest gymnastic theories. The final six days comprised of 'international camp' in which various teams could mix with one another. ${ }^{90}$ That the League of Health had been invited spoke to the group's connections and also its reputation. Few individuals in Ireland considered the country to be a hotbed of gymnastic activity. That Ireland did not boast a state physical education school until the 1970s meant that it was roughly

\footnotetext{
${ }^{83}$ Ríona Nic Congáil, 'Looking on for Centuries from the Sideline: Gaelic Feminism and the Rise of Camogie', Éire-Ireland 48, no. 1 (2013), 168-190.

${ }^{84}$ Diane Palmason, 'In Praise of Older Women Athletes', Canadian Woman Studies 4, no. 3 (1983), 50-54.

${ }^{85}$ Heffernan, 'Fitness and fun', 1020-1030.

${ }^{86}$ Ainsworth, 'The International Scene-Summer, 1949'.

${ }^{87}$ Ibid., 629.

${ }^{88}$ Gladys Andrews, 'The Universal Child', Journal of the American Association for Health, Physical Education, and Recreation 21, no. 7 (1950): 26-28.

${ }^{89}$ Smithells, 'Going to the Lingiad?'

90 Ibid.
} 
a century behind many of its European contemporaries. ${ }^{91}$ Ireland was, relative to other countries, behind in supporting women's sport or physical activity. This explains part of the excitement underpinning the League's appearance among League members. The League had not been invited in 1939 and, even if it had, would likely have found travel difficult. 1949, on the other hand, presented an opportunity to represent Ireland on a significant world stage.

This explains the efforts of the League of Health to exhibit themselves as a distinctly Irish team in attire and demonstration. Part of the League's fundraising concerns related to new uniforms. Choosing the women's attire had, in the past, been a somewhat controversial issue as evidenced by McQuaid's intrusion in the League's creation in the Free State. Few individuals outside the league raised objections, however, when the League announced that they would wear their own version of an Irish uniform. ${ }^{92}$ Where previously the League's uniform was dictated by the English branch, albeit with some modifications, the uniform worn at the Lingiad spoke to their Irish heritage. Rather than the white tunic and black shorts with skirt combination synonymous with the League in Ireland, those who travelled to Sweden were given a new uniform consisting of a green and white athletic dress. This was complimented by team jackets with Ireland (written in English) emblazoned across the back. ${ }^{93}$

Remarkably, one of the League's members recorded her experiences of the event. The previously photographed Isolde McCullough published a memoir in 2004, which reflected on her time at the Lingiad. In it she writes of the team's excitement in participating, in meeting with women from different regions and escaping to something entirely different. This was, as McCullough pointed out, different to the annual trips the League made to London for displays. ${ }^{94}$ Where the London trips were done in the context of a broader League gathering, this was an international event in which women from different organisations met and exchanged ideas. This later led to some rather fascinating exchanges between Irish and European teams, as discussed later in this piece. Returning to Isolde's memoirs, it is clear that the fact that the women self-financed the trip was a point of considerable pride for those involved. ${ }^{95}$ As journalist Anna Kelly noted prior to the Lingiad, other nations had funded their own teams, but the Irish had not. ${ }^{96}$

Although small in numbers, the League's involvement appears to have been commented upon favourably by some in the Swedish press. The Irish team was even part of the promotional material shown during and after the Lingiad. A video shows Kathleen O'Rourke leading the League's procession with a large green flag with Ireland written across it during a display of nations' flags (Fig. 4). Later in the clip, Ireland are shown again, as the team demonstrates an Irish jig during a public exhibition. Situated between clips of other nations, the video suggests the presence of the Irish team was treated with equal importance to much larger nations.

\footnotetext{
${ }^{91}$ Thomas A. O'Donoghue, 'Sport, recreation and physical education: the evolution of a national policy of regeneration in Eire, 1926-48', The International Journal of the History of Sport 3, no. 2 (1986): 231.

92 'Irish Girl Gymnasts Impress at Stockholm', Irish Press, 1 August 1949, 5.

${ }^{93}$ Ibid.

${ }^{94}$ McCullagh, Isolde's Way, 91-95.

${ }^{95}$ Ibid.

${ }^{96}$ Kelly, 'League of Health'.
} 


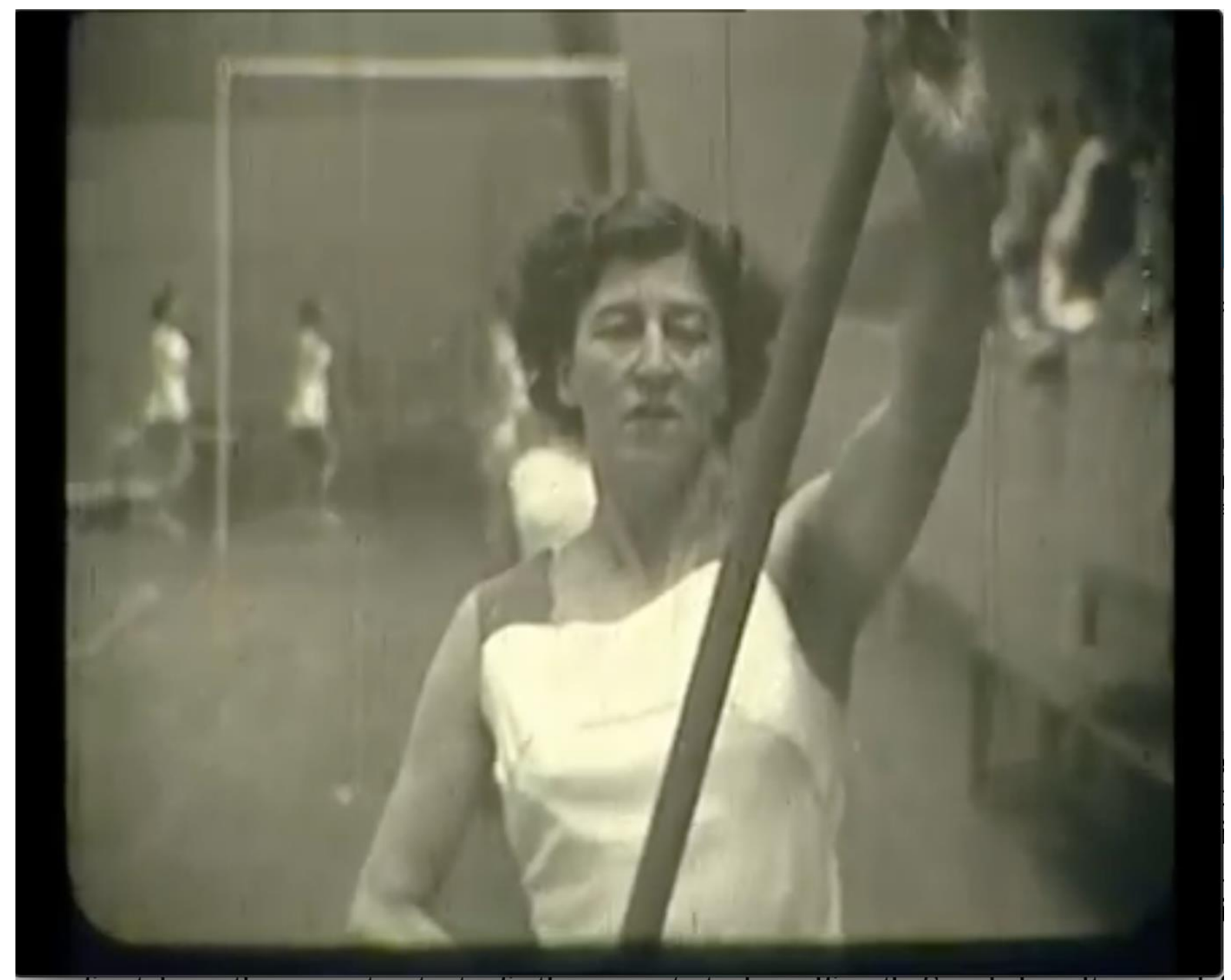

Fig. 4. Kathleen O'Rourke leading Ireland at the Lingiad. ${ }^{97}$

That the Irish team was featured waving the tricolour flag was treated with great excitement by the Irish media, who reported on the League's appearance at the festival. ${ }^{98}$ Given the relative dearth of international sporting representation for women, it was also an unusual, but significant achievement.

Such discourses were furthered in the days following the festival, especially during reports of the team's homecoming. On returning to Dublin airport in early August, the team was praised for integrating so well with their foreign hosts - an appraisal exemplified by a farewell party given by their Swedish hosts. During the night's proceedings, the League had taken the time to teach the Swedish teams, and a host of onlookers, the 'Walls of Limerick' dance. ${ }^{99}$ On a more serious cultural note, several newspapers applauded Kathleen O'Rourke for taking the opportunity to further ingratiate herself with Swedish culture and Swedish teachings. When the team returned home from Sweden in August 1949, missing from the party was O'Rourke, who had decided to stay on in Sweden to undertake a special course in physical training. ${ }^{100}$ Accompanying such praise was the rumour that O'Rourke was contemplating taking a Finnish physical educationalist to Ireland to further the cause of women's gymnastics in Ireland. ${ }^{101}$

\footnotetext{
97 'DGI - Lingiade i Stockholm 1949', DGI, 16 May 2019, https://www.youtube.com/watch?v=rXMgNJbb8Nw.

98 'Irish Tricolor in Sweden', Irish Independent, 2 August 1949, 5.

99 'Physical Culture Team Returns', Irish Independent, 8 August 1949, 6.

${ }^{100}$ Ibid.

${ }^{101}$ Ibid.
} 
Perhaps unsurprisingly, the media attention given to the League's exploits before, during and after the Lingiad helped push more Irishwomen into League classes. ${ }^{102}$ Certainly, Isolde's memoirs spoke of the renewed interest of Irishwomen in the League following their return home from Sweden. ${ }^{103}$ This was perhaps unsurprising. One stream in Irish sport history writing has reiterated the importance of the media in supporting, and advertising, sporting organisations within the country. ${ }^{104}$ Rather than an objective observer of events, the media has continually played a role in attracting interest and/or creating drama in Irish sport. In the realm of women's sport, Katie Listen and Mary O'Connor's study of modern media in Ireland made clear the importance (or lack thereof) of media coverage for women's sport. ${ }^{105}$ Increased attention for the League follows Listen and O'Connor's assertion that media coverage can increase interest and participation in women's exercise/sport. As the League was one of the few outlets open to women across the life cycle, this was an important effect. Some of these members may have been temporary, but others remained, often for several decades.

The Lingiad trip also led to a series of international exchanges between Swedish and Irish gymnastic groups. Claims in August 1949 that O'Rourke was planning to bring a Finnish physical educationalist to Ireland proved unfounded but they were not without some other merit as O'Rourke did organise several cultural exchanges for Swedish gymnastic teams and gymnasts. In 1950, O'Rourke helped to facilitate the Central Gymnastic Institute's tour of Ireland. The Institute, based in Stockholm, briefly toured Ireland in 1950 owing to the League's connections and the petitioning of local vocational committees to help partly fund the tours. ${ }^{106}$ The Institute's team was a mixture of adults and adolescents who toured Leinster and Munster for several weeks, giving exhibitions, demonstrations and lectures. Later trips that year involved gymnastic teams from Sofia and Germany, both of whom O'Rourke met during the League's time in Sweden. ${ }^{107}$

Writing on the Sofia Girls Team in the Irish Independent in March 1950, one unnamed journalist made clear the impact that O'Rourke and the League were having on physical culture in Ireland for women, writing that 'Ireland had made a promising start in physical culture, thanks to the lead given by Miss Kathleen O'Rourke'. ${ }^{108}$ Equally important was the opportunity such functions gave to women visiting Ireland for the first time. Prior to the League's trip to Sweden and, in the midst of fundraising concerns, journalists suggested that the League's Lingiad appearance would serve as a great advertisement for the country. ${ }^{109}$ Such trips gave validity to their claims. It appears that long-term friendships were forged with O'Rourke and many of her foreign counterparts, as evidenced by sporadic foreign tours to Ireland made in later years. ${ }^{110}$ The League's Lingiad trip may not have been a competitive outing, but it provided a boost to female physical culture in terms of additional membership, greater exposure and, most importantly, public support.

\footnotetext{
102 McCullagh, Isolde's Way, 91-95.

103 Ibid.

${ }^{104}$ Seán Crosson, and Phillip Dine, 'Sport and the Media in Ireland: an introduction', Media History 17, no. 2 (2011): 109-116.

${ }^{105}$ Katie Liston and Mary O'Connor, 'Media Sport, Women and Ireland: Seeing the wood for the trees', in Sport, the Media and Ireland: Interdisciplinary Approaches, eds. Neil O’Boyle and Marcus Free (Cork: Cork University Press, 2020), 133-149.

106 'Noted Gymnasts for Dublin', Evening Herald, 10 February 1950, 2.

${ }^{107}$ Ibid.; 'Swedish Gymnasts for Galway?' Connacht Tribune, 4 February 1950, 16.

108 'Swedish Team Welcomed', Irish Independent, 2 March 1950, 7.

${ }^{109}$ Kelly, 'League of Health'.

110 'Swedish Team Welcomed', Irish Independent.
} 


\section{Conclusion}

At the time of writing, the League of Health continues to operate in Ireland under a new moniker, The Fitness League. Groups continue to travel to Great Britain every year for an annual League display and although catering primarily towards a senior demographic, the League still advertises itself to women, and occasionally men, across the life cycle. ${ }^{111}$ Such continuities are tempered by the fact that where the League was once unique in providing exercise classes for women in Ireland, they are now forced to compete with dozens of other groups. The relative explosion of interest in women's keep-fit in Ireland, which began to take fuller effect in the 1980s, has somewhat lessened the League's significance in Ireland. ${ }^{112}$ The contrast with the 1940s and 1950s could not be starker. The League once represented an allfemale group at a period in Irish history when such organisations were almost nonexistent in a sporting or athletic sense. Finally, the League was often taken to be an authority in this field as illustrated by Kathleen O'Rourke's regular articles on female exercise.

That it was the League who represented Ireland at the Lingiad is not surprising. After all, there were few organised female groups to choose from. That the League was invited to the Lingiad is somewhat confusing. Here was a group that was, although sizeable relative to the population, miniscule on a global stage. The Irish League came from a country which had provided little in the way of new training theories or systems and was, by dint of its origins, differentiated from the rest of the Women's League of Health and Beauty. The League's inclusion spoke to its transnational links as fostered with the home branch in Great Britain as well as the organiser's desire to expand the festival's remit. This extended the League's remit, and more importantly, its visibility. On invitation to the Lingiad the Irish League found itself in the situation of having to fund a trip that in other parts of the world was funded by the government. This was not unique to the League in Ireland - the 1948 Olympians being just one other example — but it did highlight some of the material constraints facing them. That the League managed to do so pointed to its popularity and public base within the country.

At an individual level, the League's time in Sweden provided Irishwomen with a unique opportunity: the chance to represent Ireland at an international gathering. It was an entertaining and fun trip but also one, which League memoirs make clear, that instilled in members a sense of pride. For the Irish press, the League's trip to Sweden provided an unusual story about athletic women travelling abroad, self-funding their efforts and helping, in part, to strengthen female physical activity in Ireland. This was not a moment-defining trip. Women's involvement in the League increased after Sweden but on the whole female physical activity was still restricted. It was, however, an indication that, given the right platform and the right circumstances, female exercisers in Ireland could take a much greater public role and importance. This was shown, most obviously, in the case of Kathleen O'Rourke who helped organise several cross-country gymnastic trips for foreign female exercisers to Ireland.

Writing in 1934, soon before her death, the League's founder Mary Bagot Stack expressed her hope that 'the health training and happy social contacts which we Members find in our League are going to help us in our little corner of this vast universe to grow a few humble flowers'. ${ }^{113}$ That the League continues to this day perhaps validates her hopes. In the Irish context, the Lingiad trip spoke to the advancing nature of female exercise in Ireland. Barriers still existed, but not as many, and not as strongly, as in previous years.

\footnotetext{
${ }^{111}$ Fitness League, 'Welcome to the Fitness League', accessed 6 May 2021, https://fitnessleague.co.za.

112 ‘Aerobics Can Damage Your Health', Sunday Independent, 1 April 1984, 9.

${ }^{113}$ Bagot Stack, The Romance of the League, 4.
} 


\section{References}

‘Aerobics Can Damage Your Health'. Sunday Independent, 1 April 1984.

'Baby Must Go Too'. Belfast Telegraph, 28 July 1949.

'Day to Day'. Irish Press, 26 July 1949.

'DGI - Lingiade i Stockholm 1949'. 16 May 2019.

https://www.youtube.com/watch?v=rXMgNJbb8Nw.

'Health League Girls Leave for Sweden'. Irish Press, 26 July 1949.

'How we Grow'. Mothers and Daughters 14 (1935): 11.

'Irish Girl Gymnasts Impress at Stockholm'. Irish Press, 1 August 1949.

'Irish Tricolor in Sweden'. Irish Independent, 2 August 1949.

'Larne'. Health and Beauty 39 (1939): 30.

‘League of Health Team for Sweden'. Evening Herald, 5 July 1949.

'League of Health'. Belfast Newsletter, 21 February 1940.

'News from Northern Ireland'. Health and Beauty 30 (1937): 34.

'News from the Branches'. Health and Beauty 1 (1933): 41.

'News from the Centres'. Mothers and Daughters 10 (1934): 13.

'Noted Gymnasts for Dublin'. Evening Herald, 10 February 1950.

'Physical Culture Team Returns'. Irish Independent, 8 August 1949.

‘Swedish Gymnasts for Galway?'. Connacht Tribune, 4 February 1950.

'Swedish Team Welcomed'. Irish Independent, 2 March 195.

'The League of Health'. Irish Independent, 26 July, 1949.

‘The Women's League of Health and Beauty'. Health and Beauty 39 (1939): 2.

‘Women’s Progressive Union'. Dublin Daily Express, 15 February 1899.

Ainsworth, Dorothy S. 'The International Scene-Summer, 1949'. Journal of the American Association for Health, Physical Education, and Recreation 20, no. 9 (1949): 573629.

Andrews, Gladys. 'The Universal Child'. Journal of the American Association for Health, Physical Education, and Recreation 21, no. 7 (1950): 26-28. 
Ashburner, Lynn. In a League of Their Own: The Story of the Women's League of Health and Beauty. London: Heritage Books, 2005.

Bagot Stack, Mary. Building the Body Beautiful. London: Chapman and Hall, 1931. Seventh impression, 1938.

. The Romance of the League. London: The Women's League of Health and Beauty, 1934.

Beaumont, Caitriona. 'Women, citizenship and Catholicism in the Irish free state, 19221948'. Women's History Review 6, no. 4 (1997): 563-585.

Champion, Sheila. Irish Amateur Gymnastics Association: History of the First 25 Years. Dublin: IAGA, 1989.

Congáil, Ríona Nic. "'Looking on for Centuries from the Sideline": Gaelic Feminism and the Rise of Camogie'. Éire-Ireland 48, no. 1 (2013): 168-190.

Cooney, John. John Charles McQuaid: Ruler of Catholic Ireland. Syracus: Syracuse University Press, 2000.

Cronin, Maura. 'Class and status in twentieth-century Ireland: the evidence of oral history'. Saothar 32 (2007): 33-43.

Crosson, Seán, and Phillip Dine. 'Sport and the Media in Ireland: an introduction'. Media History 17, no. 2 (2011): 109-116.

Curran, Conor. 'The development of physical education in Northern Ireland, 1922-1953 an the role of Joan Burnett Knight'. Sport in Society 23, no. 8 (2020): 1-21.

Daly, Mary E. 'Women in the Irish Free State, 1922-39: the interaction between economics and ideology'. Journal of Women's History 7, no.1 (1995): 99-116.

Fanning, Ronan. 'Irish neutrality: An historical review'. Irish Studies in International Affairs 1, no. 3 (1982): 27-38.

Faughnan, Sean. 'The Jesuits and the Drafting of the Irish Constitution of 1937'. Irish Historical Studies 26, no. 101 (1988): 79-102.

Fitness League. 'Welcome to the Fitness League'. Accessed 6 May 2021. https://fitnessleague.co.za.

Hampton, Janie. The Austerity Olympics: When the Games Came to London in 1948. London: Aurum Press Limited, 2012.

Heffernan, Conor. 'Fitness and fun that's not just for mum: the Women's League of Health and Beauty in 1930s Ireland'. Women's History Review 28, no. 7 (2019): 1017-1038.

—. 'Physical culture and Irish modernity, 1893 to 1918'. Leisure/Loisir 43, no. 2 (2019): 159-184.

Kelly, Anna. 'League of Health'. Irish Press, 23 June 1949. 
Keys, Barbara. 'The early Cold War Olympics, 1952-1960: Political, economic and human rights dimensions'. In The Palgrave Handbook of Olympic Studies, edited by Helen Jefferson Lenskyj and Stephen Wagg, 72-87. London: Palgrave Macmillan, 2012.

Liston, Katie and Joseph Maguire. 'Making sense of 'Ireland', sport and identity: the craft of doing sociology'. Sport in Society 23, no. 10 (2020): 1-19.

and Mary O'Connor, 'Media Sport, Women and Ireland: Seeing the wood for the trees'. In Sport, the Media and Ireland: Interdisciplinary Approaches, edited by Neil O’Boyle and Marcus Free, 133-149. Cork: Cork University Press, 2020.

Lucey, John. 'Women's Hockey in Ireland - A Short History'. History Ireland 26, no. 5 (2018): 44-47.

Macrae, Eilidh. Exercise in the Female Life-cycle in Britain, 1930-1970. Basingstoke: Palgrave Macmillan, 2016.

Maguire, Joseph. 'European body cultures and the making of the modern world: Zones of prestige and established-outsider relations'. Human Figurations 1, no. 1 (2012).

Matthews, Jill Julius. 'They had such a lot of fun: The Women's League of Health and Beauty between the wars'. History Workshop Journal 30, no. 1 (1990): 22-54.

McCullagh, Isolde. Isolde's Way. Wicklow: Self-Published, 2004.

Morris, Ivan. A History of Women's Golf in Ireland. Dublin: Liberties Press, 2018.

O'Donoghue, Thomas A. 'Sport, recreation and physical education: the evolution of a national policy of regeneration in Eire, 1926-48'. The International Journal of the History of Sport 3, no. 2 (1986): 231.

O’Rourke, Kathleen. 'Learning to Relax'. Irish Press, 2 November 1946.

—_. 'Taking Off Surplus Fat'. Irish Press, 5 December 1946.

Oldfield, Samantha. 'The origins and formation of England Netball'. International Sport and Leisure History Colloquium, Manchester Metropolitan University, 3-4 March 2017, Crewe, UK.

Palmason, Diane. 'In Praise of Older Women Athletes'. Canadian Woman Studies 4, no. 3 (1983), 50-54.

Polley, Martin. The British Olympics: Britain's Olympic Heritage 1612-2012. Swindon: English Heritage, 2012.

Raftery, Deirdre and Catriona Delaney. "'Un-Irish and un-Catholic": sports, physical education and girls' schooling'. Irish Studies Review 27, no. 3 (2019): 325-343.

Smithells, Philip A. 'Going to the Lingiad?'. Journal of the American Association for Health, Physical Education, and Recreation 20, no. 2 (1949): 91-94.

Stack, Prunella. The Way to Health and Beauty. London: Self-Published, 1938. 
The Editor. 'Personalities: Mrs. King'. Mother and Daughter 7 (1934): 32.

The League of Ireland. Diamond Jubilee 1934-1994 Booklet. Dublin: Self-Published, 1994.

Todd, Jan. Physical Culture and the Body Beautiful: Purposive Exercise in the Lives of American Women, 1800-1875. Macon: Mercer University Press, 1998.

Vertinsky, Patricia. "'Building the Body Beautiful” in The Women's League of Health and Beauty: yoga and female agency in 1930s Britain'. Rethinking History 16, no. 4 (2012): 517-542.

Wichmann, Angela. 'Diversity versus unity: a comparative analysis of the complex roots of the World Gymnaestrada'. The International Journal of the History of Sport 32, no. 4 (2015): 614-629.

Zweiniger-Bargielowska, Ina. 'The Making of a Modern Female Body: beauty, health and fitness in interwar Britain'. Women's History Review 20, no. 2 (2011): 299-317. 